\section{Relationship between cognitive impairment and functional disability in nursing home residents}

Jelena R. Pavlovic ${ }^{1}$, Maja N. Racic ${ }^{2}$, Nedeljka M. Ivkovic

Department of Nursing, School of Medicine, University of East Sarajevo,

Department of Primary Health Care and Public Health, School of Medicine, University of Sarajevo, ${ }^{3}$ Department of Oral Rehabilitation, School of Medicine, University of East Sarajevo; Bosnia and Herzegovina

\section{Abstract}

Introduction: Cognitive abilities are defined as the awareness of immediate discovering, rediscovering, and recognizing information in various forms, understanding, and comprehension.

Objective: To examine the cognitive impairment rate and its effect on the functional status of elderly persons, retirement home beneficiaries.

Method: The research has been designed as a crosssectional study, including 110 elderly persons. Research instruments comprised a general questionnaire, Katz index of independence in activity of daily living, Lawton instrumental activities of everyday life, and Mini-mental state examination. The statistical test used was the $\chi 2$ test, while Pearson's correlation analysis was used for correlation analysis.

Results: Out of the total number of subjects, $60 \%$ had an impaired cognitive status. When it comes to functional status, assistance was necessary for $79.2 \%$ of the subjects. Statistically significant weak positive correlation existed between the subjects' cognitive status and their functional abilities $(\mathrm{r}=0.331 ; \mathrm{p}<0.001 ; \mathrm{r}=0.386 ; \mathrm{p}<0.001)$.

Conclusion: The cognitive deficit rate was high in the retirement home subjects. Cognitive deficit brings about a significant decline intellectual functioning and undermines the subjects' daily living activities. deficit.

\section{Veza između kognitivnog oštećenja i funkcionalne nesposobnosti kod lica koja žive u staračkim domovima}

Jelena R. Pavlovićl, Maja N. Račićn ${ }^{2}$,Nedeljka M. Ivković ${ }^{3}$

Zdravstvena njega, Medicinski fakultet, Univerzitet u Istočnom Sarajevu,

'Katedra porodične medicine, Medicinski fakulteUniverzitet u Istočnom Sarajevu

${ }^{3}$ Stomatološki fakultet, Medicinski fakultet, Univerzitet u Istočnom Sarajevu;

Bosna i Hercegovina

\section{Sažetak}

Uvod. Kognitivne sposobnosti se definišu kao svest o neposrednom otkrivanju, ponovnom otkrivanju i prepoznavanju informacija u različitim oblicima, razumevanje i shvatanje.

Cilj rada. Ispitati stepen kognitivnog oštećenja i njegove efekte na funkcionalni status starijih osoba koje žive u staračkim domovima.

Metod. Istraživanje je dizajnirano kao studija preseka i obuhvatilo je 110 starijih lica. Kao instrumenti istraživanja korišćeni: su opšti upitnik, Katzov indeks nezavisnosti za aktivnosti u svakodnevnom životu, Lawtonova skala aktivnosti u svakodnevnom životu i Mini-mental skala kognitivnih sposobnosti. Od statističkih testova koristili smo $\chi^{2}$ test, a Pearsonova korelacijska analiza korišćena je za analizu korelacije.

Rezultati. Od ukupnog broja ispitanika, 60\% je imalo oštećen kognitivni status. Što se tiče funkcionalnog statusa, $79.2 \%$ ispitanika je zahtevalo pomoć. Statistički značajna, slaba pozitivna korelacija uočena je između ispitanikovog kognitivnog statusa $\mathrm{i}$ njegovih funkcionalnih sposobnosti $(\mathrm{r}=0.331 ; \mathrm{p}<0.001 ; \mathrm{r}=0.386 ; \mathrm{p}<0.001)$.

Zaključak. Stopa kognitivnog deficita među licima koja žive u staračkim domovima je bila visoka. Kognitivni deficit dovodi do značajnog pada intelektualnog funkcionisanja i narušava svakodnevne aktivnosti starih osoba.

Ključne reči: Stara osoba, funkcionalni status, kognitivni deficit 


\section{Introduction}

Cognitive decline and dementia represent a significant social and health problem, generating a substantial impact on the functional abilities and dependence status of the patients ${ }^{1}$. Despite this, there is a lack of programs and strategies providing help to subjects with dementia and other cognitive deficits preventing the onset of the disease. Literature has shown there is a relationship between lifestyle and cognitive decline. Indeed, an active lifestyle maintained after retirement can help the mental performance of the elderly ${ }^{2}$. It is well known that insufficient social engagement is associated with a low quality of life as well as many adverse health outcomes, such as functional decline and mortality ${ }^{3}$. Physical activity, even at moderate levels, and participation in recreational activities, may have a protective effect on mental function and the incidence of dementia ${ }^{4}$. Disturbances in physical functioning ultimately lead to cognitive impairments and chronic medical problems 5 .

However, the current model of secondary health care for older adults plays an important role in slowing cognitive functioning decline $e^{6,7}$.

\section{Objective}

Cognitive impairment is prevalent in practice, but the major problem is that it is rarely diagnosed, which brings about numerous collaborative issues. Information about the cognitive disorder rate in elderly persons staying in retirement homes is scarce, which indicates the significance of studying old age cognitive disorders. Early diagnostics and timely treatment of cognitive disorders in elderly persons is of the essence, through the application of psychosocial interventions and medicinal treatment, as well as the promotion of active and healthy aging also matters. This extensive treatment needs to be carried out as a team effort, employing a multi-professional team (physicians, nurses, therapists, neurologists, and psychiatrists), all trained geriatric experts. The objective of the investigation is to examine the rate of cognitive impairment and its effect on the functional status of elderly persons in retirement homes.

\section{Method}

The cross-sectional study included nursing home residents older than 65 years of age. The correspondence with the nursing homes located in the region of East Sarajevo confirmed that 186 elderly individuals were nursing home residents at the time of the survey. Of those, 12 were palliative care users, 7 had advanced dementia, and 9 were disabled patients. The sample size calculation was conducted, and with a population size of 158 , allowing for an error margin of $5.3 \%$ with a $95 \%$ confidence interval $(\mathrm{CI})$, the minimal required number of responses was determined to be 108 . The
Veza između kognitivnog oštećenja i funkcionalne nesposobnosti kod lica koja žive u staračkim domovima Opšta medicina 2020;26(1-2):24-30

\section{Uvod}

Pad kognitivnih funkcija i demencija predstavljaju značajan društveni i zdravstveni problem i imaju veliki uticaj na funkcionalne sposobnosti i nezavisnost $\mathrm{u}$ funkcionisanju kod ovih pacijenata ${ }^{1}$. Uprkos tome, ne postoji dovoljno programa i strategija koje bi obezbedile pomoć licima sa demencijom i drugim kognitivnim deficitima, a koji bi sprečili nastanak bolesti.

Literatura je pokazala da postoji veza između životnog stila i kognitivnog pada. I zaista, aktivan životni stil nakon penzionisanja može pomoći i održanju mentalnih performansi kod starih osoba ${ }^{2}$. Dobro je poznato da je siromašna društvena aktivnost povezana sa lošijim kvalitetom života, kao i sa mnogim drugim lošim zdravstvenim ishodima, kao što je funkcionalni pad i smrtnost ${ }^{3}$. Fizička aktivnost, čak i umerena, kao i učešće u rekreativnim aktivnostima može imati protektivni efekat na mentalnu funkciju i učestalost demencije ${ }^{4}$. Problemi u fizičkom funkcionisanju neminovno vode ka kognitivnom oštećenju i hroničnim zdravstvenim problemima ${ }^{5}$ Trenutni model sekundarne zdravstvene zaštite za starije pacijente ima značajnu ulogu u usporavanju pada kognitivne funkcije $\mathrm{e}^{6,7}$.

\section{Cilj rada}

Kognitivno oštećenje je često u praksi, ali glavni problem je što se retko dijagnostikuje, što dovodi do brojnih dodatnih problema. Informacije o procentu kognitivnih poremećaja kod starih osoba koje žive u staračkim domovima su minimalne, što ukazuje na značajnost istraživanja kognitivnih poremećaja kod starih. Rana dijagnoza i pravovremeno lečenje kognitivnih poremećaja kod starih lica su najbitniji, mada je i primena psihosocijanih intervencija i medikamnetoznog lečenja kao i promocija aktivnog i zdravog starenja takođe važna. Sveobuhvatno lečenje treba sprovesti kao timski napor, uključujuči tu multiprofesionalni tim (lekari, sestre, terapeuti, neurolozi i psihijatri) obučenih gerijatriskih eksperata. Cilj ovog istraživanja je da se ispita stopa kognitivnog oštećenja i njen efekat na funkcionalni status starih osoba u staračkim domovima.

\section{Metod}

Studija preseka obuhvatila je lica koja žive u staračkim domovima, starosti preko 65 godina. U komunikaciji sa staračkim domovima u regionu Istočnog Sarajeva saznali smo da u njima boravi 186 lica, u vreme kada smo radili istraživanje. Od ovih osoba, 12 je imalo palijativnu negu, 7 je imalo uznapredovalu demenciju, a 9 je bilo nepokretno. Proračunata je veličina uzorka i sa uzorkom od 158 ispitanika dozvoljen je rizik greške od $5.3 \%$ sa intervalom poverenja 
management of nursing homes was informed about the aims of the study; their agreement was sought and obtained. Inclusion criteria were an orientation in time, place and person, and informed consent for taking part in the survey. Older adults with poor general health conditions, disorientation, and lack of cooperation were excluded from the study. 126 elderly nursing home residents met selection criteria, but the research included $110(87.3 \%)$ of them since 16 subjects did not agree to participate in the study.

At the beginning of the study, all subjects were informed about the objectives of the research and the procedure to be carried out was explained in detail. A sociodemographic questionnaire (subjects' gender, age, and social status, social activity and integration - cohabitation, socialization, hobbies), Katz index of independence in activity of daily living (ADL), Lawton instrumental activities of daily living (IADL) and Mini-mental state examination (MMSE) were used in this study. The questionnaires were translated into the Bosnian language and pretested previously ${ }^{7}$. Questions about sociodemographic characteristics were read to the subjects, and their answers were recorded by the principal researcher.

Lawton scale ${ }^{8}$ was used to rank six basic functions (taking a bath, dressing up, hygiene, movement, incontinence, and nutrition). The Lawton Scale consists of 8 items. The overall score ranges from 0 (low functioning) to 8 (high functioning).

The Cronbach $\alpha$ coefficient for the Lawton scale was 0.853. Katz index assessed functional status ${ }^{9}$ as a measurement of the subject's ability to perform activities of daily living independently. The activities were evaluated on an ordinal scale - from 0 - 6 points, indicating independence. to complete helplessness if $>118$. Cronbach's alpha coefficient was calculated to assess the reliability, and its value of 0.912 showed a high degree of internal homogeneity for the Katz index.MMSE scale ${ }^{10}$ is an overview of mental status and investigators assessed orientation in space and time, immediate repetition of three words, delayed recall of the three words, serial deduction "100-7", carrying out a three-layer verbal order, the naming of two objects, repetition of a phrase difficult to pronounce, the reading of a written order and its execution, the writing of a grammatical sentence, drawing a pentagon image. Every subject gets one point for each correct answer, with the maximum number of points being 30 . The reliability of the MMSE was adequate $(\alpha=0.774)$. The number of points below 20 marks a cognitive impairment ${ }^{10}$. The study was carried out in the period from May 1st, 2016, to December 1st, 2016. The statistical package for social sciences (SPSS) was used for data processing in this investigation. Statistically, a difference significance was established by the $\chi 2$ test, while the Pearson correlation analysis was used for association analysis, and it was estimated based on the significance level $\mathrm{p}<0.05$.

All participants signed the informed consent form. The authors concealed the participants' identities. od 95\% (IP) i određeno je da minimalan broj zahtevanih odgovora bude 108. Uprava staračkih domova obaveštena je o ciljevima studije; tražili smo i dobili njihov pristanak. Kriterijumi za uključivanje u studiju su bili orijentacija u prostoru, vremenu i prema ljudima i informisani pristanak za učešće u studiji. Starije osobe lošeg zdravlja, dezorijentisane i koje ne sarađuju su isključene iz studije. Ukupno 126 stanovnika staračkih domova ispunilo je kriterijume, ali je uključeno njih $110(87.3 \%)$ jer je 16 odbilo da učestvuje u studiji.

$\mathrm{Na}$ početku studije, svi ispitanici su informisani o cilju studije i sve procedure su im detaljno objašnjene. Sociodemografski upitnik (ispitanikov pol, godište, društveni status, društvena aktivnost i integracija - kohabitacija, socijalizacija, hobiji), Katzov indeks nezavisnosti za aktivnosti u svakodnevnom životu (ADL), Lawtonova skala aktivnosti u svakodnevnom životu (IADL) i Mini-mental skala kognitivnih sposobnosti su upotrebljene u studiji. Upitnici su prevedeni na bosanski jezik i prethodno isprobani ${ }^{7}$. Pitanja o sociodemografskim karakteristikama su pročtana ispitanicima, a njihove odgovore je zabeležio glavni istraživač.

Lawtonova skala ${ }^{8}$ korišćena je za rangiranje šest osnovnih funkcija (kupanje, oblačenje, higijena, kretanje, inkontinencija i ishrana). Lawtonova skala ima 8 pitanja. Ukupan broj bodova kreće se od 0 (slabo funkcionisanje) do 8 (dobro funkcionisanje).

Cronbachov $\alpha$ koeficijent za Lawtonovu skalu je bio 0.853. Katzov indeks je procenjivao funkcionalni status ${ }^{9}$, kao mera ispitanikove sposobnosti da samostalno izvršava svakodnevne aktivnosti. Aktivnosti su procenjivane na skali od $0-6$ bodova (označava nezavisnost) do $>118$ (potpuna bespomoćnost). Cronbachov alfa koeficijent je proračunat da bi se procenila pouzdanost i njena vrednost od 0.912 pokazala je visok stepen unutrašnje homogenosti za Katzov indeks. MMSE skala ${ }^{10}$ obuhvata pregled mentalnog statusa $i$ istraživači su procenjivali orijentaciju u vremenu i prostoru, neposredno ponavljanje 3 reči, odloženo ponavljanje 3 reči, brojanje unazad od 100 za po 7 , izvršavanje troslojne verbalne naredbe, imenovanje 2 objekta, ponavljanje fraze koju je teško izgovoriti, čitanje napisane naredbe i njeno izvršenje, pisanje gramatički ispravne rečenice, crtanje pentagona povezivanjem tačaka. Svaki tačan odgovor nosi jedan poen, a maksimalan broj je 30 poena. Pouzdanost MMSE testa je bila adekvatna ( $\alpha=0.774)$. Broj poena ispod 20 označava kognitivno oštećenje. ${ }^{10}$ Studija je sprovedena u periodu od 01. maja 2016. do 01. decembra 2016. Statistički paket za društvene nauke (SSPS) korišćen je za obradu podataka u našem istraživanju. Statistički, značajnost razlike određivana je $\chi^{2}$ testom, dok je Pearsonova korelacijska analiza korišćena za asocijacisku analizu i procenjivana je na nivou značajnosti $\mathrm{p}<0.05$.

Svi učesnici su potpisivali pisani pristanak za učešće u studiji. Autori su sakrili identitet učesnika. 


\section{Results}

The study included 110 subjects aged 70 and over. Of those, $72.7 \%$ were females and $27.3 \%$ males. Twentysix percent of the subjects needed assistance in performing basic daily activities $\left(\chi^{2}=13.911 ; \mathrm{p}<0.001\right)$, and $52.5 \%$ had limitations in performing instrumental daily activities $\left(\chi^{2}=17.328 ; \mathrm{p}<0.001\right)$.

Out of the total number of the subjects with functional limitations, estimated by the use of ADL, $25.5 \%$ of those for whom help was necessary had cognitive dysfunctions $(p<0.004)$, and $6.4 \%$ of those in need of help, had cognitive dysfunctions. Functional limitations were estimated by the use of IADL. Out of the total number of the subjects $11.8 \%$ had cognitive dysfunctions, but in those who needed help and depended on others, $22.8 \%$ had cognitive dysfunctions $(p<0.002)$ (Table 1). A statistically significant correlation between the subjects' cognitive status and their functional ability was found. The correlation assessed through the ADL and the LDL $(r=0.331 ; p<0.001 ; r=0.386 ; p<0.001)$ turns out to be weak positive (Table 2; Table 3 ).

\section{Rezultati}

Studija je uključila 110 ispitanika, starosti preko 70 godina, od toga $72.7 \%$ su bile žene a $27.3 \%$ muškarci. Pomoć u svakodnevnim aktivnostima je bila neophodna za $26 \%$ ispitanika $\left(\chi^{2}=13.911 ; \mathrm{p}<0.001\right)$, a $52.5 \%$ imalo je ograničenja u izvršavanju svakodnevnih aktivnosti $\left(\chi^{2}=17.328\right.$; $\left.p<0.001\right)$.

Od ukupnog broja ispitanika sa funkcionalnim ograničenjima, procenjivani upotrebom ADL, 25.5\% je imalo kognitivnu disfunkciju $(\mathrm{p}<0.004)$, a $6.4 \%$ onih kojima je bila potrebna pomoć je imalo kognitivne disfunkcije. FunkcionaIna ograničenja su procenjivana upotrebom IADL. Od ukupnog broja ispitanika $11.8 \%$ je imalo kognitivnu disfunkciju, ali od onih kojima je potrebna pomoć i zavise od drugih, $22.8 \%$ je imalo kognitivnu disfunkciju $(\mathrm{p}<0.002)$ (Tabela 1$)$. Nađena je statistički značajna korelacija između ispitanikovog kognitivnog statusa i funkcionalnih sposobnosti. Korelacija procenjena preko ADL i LDL $(r=0.331 ; p<0.001$; $\mathrm{r}=0.386 ; \mathrm{p}<0.001)$ ispostavilo se bila je slabo pozitivna (Tabela 2; Tabela 3).

Table 1. Functional status of respondents assessed by ADL and IADL in relation to the cognitive function of subjects assessed using the MMSE.

Tabela 1. Funkcionalni status ispitanika procenjen uz pomoć ADL i IADL u odnosu na kognitivnu funkciju ispitanika procenjenu korišćenjem MMSE.

\begin{tabular}{|c|c|c|c|}
\hline \multicolumn{4}{|c|}{ MMSE } \\
\hline & $\begin{array}{c}\text { Damaged } \\
\text { cognitive function / } \\
\text { Oštećena kognitivna } \\
\text { funkcija }\end{array}$ & $\begin{array}{c}\text { Normal } \\
\text { cognitive function / } \\
\text { Normalna kognitivna } \\
\text { funkcija }\end{array}$ & $\mathbf{p}$ \\
\hline \multicolumn{4}{|l|}{ ADL } \\
\hline Necessary help / Neophodna pomoć & $25.5 \%$ & $5.5 \%$ & \multirow{3}{*}{0.004} \\
\hline Need help / Treba im pomoć & $6,4 \%$ & $2.7 \%$ & \\
\hline Does not need help / Ne treba im pomoć & $28.2 \%$ & $31.7 \%$ & \\
\hline \multicolumn{4}{|l|}{ IADL } \\
\hline Necessary help / Neophodna pomoć & $11.8 \%$ & $1.8 \%$ & \multirow{3}{*}{0.002} \\
\hline Need help / Treba im pomoć & $22.7 \%$ & $4.5 \%$ & \\
\hline Does not need help /Ne treba im pomoć & $25.5 \%$ & $33.7 \%$ & \\
\hline
\end{tabular}

MMSE: Mini mental state examination; ADL: Katz index of independence in activities of daily living; IADL: Lawton instrumental activities of daily living.

MMSE: Mini mental skala kognitivnih sposobnosti; ADL: Katz-ov indeks nezavisnosti u svakodnevnim aktivnostima; IADL: Lawton-ova skala aktivnosti u svakodnevnom životu. 
Table 2. Correlation coefficients between MMSE and ADL

Tabela 2. Koeficijenti korelacije između MMSE i ADL

\begin{tabular}{|c|c|c|c|}
\hline \multirow{2}{*}{ MMSE } & $\begin{array}{c}\text { Pearson } \\
\text { correlation coefficients (r) / } \\
\text { Pearson-ov koeficijent } \\
\text { korelacije (r) }\end{array}$ & MMSE & ADL \\
\hline \multirow{2}{*}{ ADL } & $\mathrm{r}$ & 1 & 0.331 \\
\cline { 2 - 4 } & $\mathrm{p}$ & $\mathrm{r}$ & 0.331 \\
\hline
\end{tabular}

MMSE: Mini mental state examination; ADL: Katz index of independence in activities of daily living.

MMSE: Mini mental skala kognitivnih sposobnosti; ADL: Katz-ov indeks nezavisnosti u svakodnevnim aktivnostima.

Table 3. Correlation coefficients between MMSE and IADL

Tabela 3. Koeficijent korelacije između MMSE i IADL

\begin{tabular}{|c|c|c|c|}
\hline & $\begin{array}{c}\text { Pearson } \\
\text { correlation coefficients (r) / } \\
\text { Pearson-ov koeficijent } \\
\text { korelacije (r) }\end{array}$ & MMSE & ADL \\
\hline \multirow{2}{*}{ MMSE } & $\mathrm{r}$ & 1 & 0.386 \\
\hline \multirow{2}{*}{ ADL } & $\mathrm{p}$ & & 0.000 \\
\hline & $\mathrm{r}$ & 0.386 & 1 \\
\hline
\end{tabular}

MMSE: Mini mental state examination; IADL: Lawton instrumental activities of daily living.

MMSE: Mini mental skala kognitivnih sposobnosti; IADL: Lawton-ova skala aktivnosti u svakodnevnom životu.

\section{Discussion}

The current study showed that the frequency of cognitive disorder $(60 \%)$ was high, which is a deficit that significantly undermines their functional status. An impaired cognitive function was found in 18 men and 48 women subjected to the study. The worst results in our research were achieved in the clock drawing test, in answering questions related to attention, delayed verbal recall, and writing. Many of our potential subjects were not able to do the test due to poor eye-sight, while their level of education also had a significant impact. The results on the ADL and the IADL have shown a diverse functional status structure. The subjects in need of assistance were mostly bed-ridden or hardly mobile at all and depended on others to perform daily activities. Based on the results of our research, it may be concluded that the analysis of data related to functional status, shows individual differences between the subjects. Our research has shown an association between cognitive and physical functioning.

\section{Diskusija}

Sadašnja studija pokazala je da je učestalost kognitivnih poremećaja kod ispitanika visoka $(60 \%)$ i to je deficit koji značajno urušava njihov funkcionalni status. Oštećena kognitivna funkcija nađena je kod 18 muškaraca i 48 žena. Najgori rezultati u našoj studiji postignuti su na testu crtanja sata, pri odgovaranju na pitanja povezanih sa pažnjom, zakasnelom verbalnom prisećanju i pisanju. Mnogi od naših potencijalnih ispitanika nisu mogli da urade test zbog lošeg vida, a i njihov nivo obrazovanja je takođe imao značajan uticaj. Rezultati ADL i IADL pokazali su različitu strukturu funkcionalnog statusa. Ispitanici kojima je bila potrebna pomoć uglavnom su bili vezani za krevet ili jedva pokretni i bili su zavisni od drugih u izvođenju svakodnevnih aktivnosti. $\mathrm{Na}$ osnovu rezultata naše studije može se zaključiti da analiza podataka povezana sa funkcionalnim statusom pokazuje individualne razlike između ispitanika. Naša studija je pokazala vezu između kognitivnog i fizičkog funkcionisanja. 
Aging is often accompanied by physiological changes that can lead to a decline in physical and cognitive capacities, often resulting in loss of autonomy or institutionalization. In the last 20 years, a large body of research has been oriented toward finding effective ways to enhance cognitive functioning in older adults or to prevent cognitive decline. Among them, physical exercise and cognitive training have demonstrated essential benefits for cognitive functioning in the older adult population ${ }^{11-13}$. The majority of nursing home residents are physically inactive ${ }^{14}$. and have an increased risk of physical, neuro cognitive impairment leading to frailty and increased mortality ${ }^{15-18 .}$ Promoting regular physical activity is considered to be an effective strategy in reducing all-cause mortality and improving quality of life among the elderly ${ }^{19}$, ${ }^{20}$. Among the elderly there are those with satisfactory functional status, those who are weak and completely dependent on other people's assistance, as well as those with different degrees of functional status deterioration risk, weakness and even death ${ }^{21}$. While a scheduled exercise routine during the hospitalization period is not recommended, if we can modify the current guidelines, it is likely that patients will show lower levels of functional and cognitive impairment after the hospitalization period, experience a better quality of life, produce lower consumption of healthcare resources (fewer readmissions and lower institutionalization), and finally, exhibit reduced mortality ${ }^{22}$. Previous studies showed that opportunities for active engagement in physical activity, including social activities, may decline with age, particularly in the presence of physical function decline and disability ${ }^{23}$. The relationship between physical activity and psychological status and cognition in older subjects has been widely studied, showing that this relation could be reciprocal. Many authors appointed that physical activity may be beneficial for cognition because higher levels of leisure time, physical activity and healthy eating seem to be protective against dementia ${ }^{24}$.

Despite the increasing number of studies, the relationship between cognitive decline and reduced physical activity remains currently unclear, and research is needed to understand better the connection between cognitive function and physical activity. The prevention of the diseases linked to cognitive decline could lead to a reduction of costs not only for patients and their families but also for the health and social welfare system. The introduction of an exercise program in hospitalized elderly patients is likely to have a significant impact both in the short and long run, by improving health care and functional parameters. We believe that, as with other medical treatments, the program should be planned, individualized, and monitored.
Proces starenja praćen je fiziološkim promenama koje mogu dovesti do smanjenja fizičkih i kognitivnih kapaciteta, što često za rezultat ima gubitak autonomije ili smeštanje u institucije. U poslednjih 20 godina mnogo studija se orijentisalo ka pronalaženju efikasnih načina da se poboljša kognitivno funkcionisanje starih osoba ili da se spreči kognitivni pad funkcija. U nekima od njih pokazano je da fizička aktivnost i kognitivni trening imaju jasnu korist za kognitivnu funkciju kod starih lica ${ }^{11-13}$. Većina lica koja žive u staračkim domovima su fizički neaktivna ${ }^{14}$ i imaju povećan rizik od fizičkog i neurokognitivnog oštećenja, što vodi slabosti i povećanju mortaliteta $^{15-18}$. Promovisanje redovne fizičke aktivnosti smatra se efikasnom strategijom u smanjenju ukupnog mortaliteta i poboljšanju kvaliteta života starijih osoba ${ }^{19,20}$. Među starima ima onih sa zadovoljavajućim funkcionalnim statusom, onih koji su slabi i onih koji u potpunosti zavise od pomoći drugih ljudi, kao i onih sa različitim stepenom pogoršanja rizika funkcionalnog statusa, slabosti ili čak i smrti ${ }^{21}$. I dok se redovna fizička aktivnost ne savetije tokom hospitalizacije, ako bismo promenili trenutne vodiče, verovatno bi pacijenti pokazali manji stepen fizičkog i kognitivnog oštećenja posle hospitalizacije, imali bolji kvalitet života, manje trošili zdravstvene resurse (manje ponovnih primanja u bolnice i manje smeštanja u institucije) i konačno imali i manji mortalitet ${ }^{22}$. Prethodne studije su pokazale da prilike za aktivno uključivanje u fizičke aktivnosti, uključujući i društvene aktivnosti, mogu biti smanjene sa godinama, naročito ako je prisutno smanjenje fizičke funkcije i inalidnost ${ }^{23}$. Veza između fizičke aktivnosti i psihološkog statusa i kognicije kod starijih osoba je dosta proučavana, ukazujući da ova veza može biti recipročna. Mnogi autori su istakli da fizička aktivnost može biti korisna za kogniciju jer veći stepen slobodnog vremena, fizička aktivnost i zdrava ishrana izgleda štite od demencije ${ }^{24}$.

Uprkos sve većem broju studija, veza između kognitivnog pada i smanjene fizičke aktivnoasti ostaje trenutno nejasna i potrebna su dalja istraživanja kako bi se bolje razumela veza između kognitivne funkcije i fizičke aktivnosti. Prevencija bolesti povezanih sa kognitivnim padom može dovesti do smanjenja troškova ne samo za pacijente i njihove porodice, već i za zdravstveni i socijalni sistem. Uvođenje programa vežbanja kod hospitalizovanih starijih pacijenata bi verovatno imalo značajan uticaj i na kraće i na duže staze, poboljšavajući tako i zdravstvenu negu i funkcionalne parametre. Verujemo da kao i kod drugih medicinskih tretmana, program treba da bude planiran, individualizovan i praćen. 


\section{Conclusion}

The cognitive disorder rate remains rather high in most retirement home beneficiaries. Identifying cognitive disorders becomes one of the multi-professional team's main tasks because a cognitive deficit brings about a significant decline in intellectual functioning and undermines daily living activities. Physical inactivity is one of the leading health risk factors affecting the elderly and is the main cause of a poorer quality of living, all of which indicates that it is necessary to have in place measures to tackle the issue. It is required to regularly apply different strategies through an individual approach, to improve the cognitive and functional abilities of elderly persons.

\section{Zaključak}

Stopa kognitivnih poremećaja ostaje visoka kod većine lica u staračkim domovima. Identifikacija kognitivnih poremećaja postaje jedan od glavnih zadataka multiprofesionalnih timova, jer kognitivni deficit dovodi do značajnog pada $\mathrm{u}$ intelektualnom funkcionisanju i pogoršava svakodnevno funkcionisanje. Fizička neaktivnost je jedan od vodećih zdravstvenih faktora rizika kod starih lica i glavni je uzrok lošijeg kvaliteta života, što nas navodi na to da je neophodno imati mere pomoću kojih bi se ovaj problem prevazišao. Neophodno je redovno primenjivati različite strategije, kroz individualni pristup, kako bi se poboljšale kognitivne i funkcionalne sposobnosti starijih lica.

\section{Literatura / Reference}

1. Tolppanen AM, Solomon A, Kulmala J, Kåreholt I, Ngandu T, Rusanen M, et al. Leisure-time physical activity from mid- to late life, body mass index, and risk of dementia. Alzheimers Dement. 2015;11(4): 434-43.

2. Zantinge EM, van den Berg M, Smit HA, Picavet HS. Retirement and a healthy lifestyle: Opportunity or pitfall? A narrative review of the literature. Eur $\mathrm{J}$ Public Health. 2014; 24(3):433-9.

3. Thomas PA. Trajectories of social engagement and mortality in late life. J Aging Health. 2012; 24(4):547-68.

4. Bauman A, Merom D, Bull FC, Buchner DM, Fiatarone Singh MA. Updating the evidence for physicalactivity: Summative reviews of the epidemiological evidence, prevalence, and interventions to promote "Active Aging". Gerontologist. 2016; 56(2): S268-80.

5. Lakhan $\mathrm{P}$, Jones $\mathrm{M}$, Wilson A, Courtney M, Hirdes J, Gray LC. A prospective cohort study of geriatric syndromes among older medical patients admitted to acute care hospitals. J Am Geriatr Soc. 2011; 59(11):2001-8

6. Zisberg A, Shadmi E, Sinoff G, Gur-Yaish N, Srulovici E, Admi H. Low mobility during hospitalization and functional decline in older adults. J Am Geriatr Soc. 2011; 59(2):266-73.

7. Matović J, Pejović J, Račić M.Comprehensive geriatric assessment of patients in Health Centre Foca. Biomedicinska istraživanja. 2013; 4 (1): 13-25.

8. Lawton MP, Moss M, Fulcomer M, Kleban MH. Multilevel assessment instrument manual for full-length MAI. North Wales PA: Polisher Research Institute; 2003.
9. Katz S, Down TD, Cash HR, Grotz RC. Progress in the development of the index of ADL. Gerontologist. 1970;10(1):20-30.

10. Foreman MD, Fletcher K, Mion LC, Simon L. Assessing Cognitive Function. Geriatric Nursing. 1996; 17: 228-33.

11. Hertzog C, Kramer AF, Wilson RS, Lindenberger U. Erichment effects on adult cognitive development: can the functional capacity of older adults be preserved and enhanced? Psychol Sci

12. Bherer L. Cognitive plasticity in older adults: effects of cognitive training and physical Public Interest. 2009; 9(1):1-65.

13. Ballesteros S, Kraft E, Santana S, Tziraki C. Maintaining older brain functionality: A targeted review. Neurosci Biobehav Rev. 2015; 55:453-77. exercise. Ann N Y Acad Sci. $2015 ; 1337(1): 1-6$.

14. den Ouden M, Bleijlevens MHC, Meijers JMM, Zwakhalen SMG, Braun SM, Tan FES, et al. Daily (In)activities of nursing home residents in their wards: an observation study. J Am Med Dir Assoc. 2015;16(11):963-8.

15. Hallal PC, Andersen L, Bull FC, Guthold R, Haskell W, Ekelund U. Lancet Physical Activity Series Working Group. Global physical activity levels: surveillance progress, pitfalls, and prospects. Lancet. 2012;380(9838):247-57.

16. Sun F, Norman I, While A. Physical activity in older people: a systematic review. BMC Public Health. 2013;13(1):449.

17. Weening-Dijksterhuis E, de Greef MH, Scherder EJ, Slaets JP, van der Schans CP. Frail institutionalized older persons: A comprehensive review on physical exercise, physical fitness, activities of daily living, and quality-of-life. Am J Phys Med Rehabil. 2011; 90(2):156-68.
18. Clegg A, Young J, Iliffe S, Rikkert MO, Rockwood $\mathrm{K}+$ Fragility in rlderly people Lancet. 2013;381(9868):752-62.

19. Brown WJ, McLaughlin D, Leung J, McCaul KA, Flicker L, Almeida OP, et al. Physical activity and all-cause mortality in older women and men. Br J Sports Med. 2012; 46(9):664-8.

20. Samitz G, Egger M, Zwahlen M. Domains of physical activity and all-cause mortality: systematic review and doseresponse meta-analysis of cohort studies. Int J Epidemiol. 2011;40(5):1382-400.

21. Mohile SG, Xian Y, Dale W, Fisher SG, Rodin M, Morrow GR, et al. Association of a cancer diagnosis with vulnerability and frailty in older Medicare beneficiaries. J Natl Cancer Inst. 2009;101(17):1206-15.

22. Martínez-Velilla N, Casas-Herrero A, Zambom-Ferraresi F, Suárez N, AlonsoRenedo J, Cambra Contín K. Functional and cognitive impairment prevention through early physical activity for geriatric hospitalized patients: study protocol for a randomized controlled trial. BMC Geriatrics. 2015;112(15):2-9.

23. Rosso AL, Taylor JA, Tabb LP, Michael YL. Mobility, disability, and social engagement in older adults. J Aging Health. 2013;25(4):617-37.

24. Van de Rest O, Berendsen AA, HavemanNies A,de Groot LC. Dietary patterns, cognitive decline, and dementia: A systematic review. Adv. Nutr. 2015;6(2):154-68.

Primljen - Accepted 09.10.2019. Ispravljen - Corrected 09.01.2020. Prihvaćen-Accepted 15.01.2020. 